\title{
Bioaccumulation of Antimony and Arsenic in Vegetables and Health Risk Assessment in the Superlarge Antimony-Mining Area, China
}

\author{
Defang Zeng, ${ }^{1}$ Saijun Zhou, ${ }^{1,2}$ Bozhi Ren, ${ }^{2}$ and Tengshu Chen ${ }^{1}$ \\ ${ }^{1}$ School of Resource and Environmental Engineering, Wuhan University of Technology, Wuhan 430070, China \\ ${ }^{2}$ College of Civil Engineering, Hunan University of Science and Technology, Xiangtan 411201, China \\ Correspondence should be addressed to Saijun Zhou; zsjaw0745@sina.com and Bozhi Ren; 564975554@qq.com
}

Received 28 July 2015; Accepted 26 August 2015

Academic Editor: Jesus Simal-Gandara

Copyright ( $\odot 2015$ Defang Zeng et al. This is an open access article distributed under the Creative Commons Attribution License, which permits unrestricted use, distribution, and reproduction in any medium, provided the original work is properly cited.

Heavy metal pollution in soils caused by mining and smelting has attracted worldwide attention for its potential health risks to residents. This paper studies the concentrations and accumulations of $\mathrm{Sb}$ and As in both soils and vegetables and the human health risks of $\mathrm{Sb}$ and As in vegetables from Xikuangshan (XKS) Sb mine, Hunan, China. Results showed that the soils were severely polluted by $\mathrm{Sb}$ and $\mathrm{As}$; $\mathrm{Sb}$ and As have significant positive correlation. $\mathrm{Sb}$ and As concentrations in vegetables were quite different: Coriandrum sativum L. was the highest in Sb, Allium fistulosum L. was the highest in As, and Brassica pekinensis L. was the lowest in both Sb and As; Daucus carota L. and Coriandrum sativum L. showed advantage in accumulating Sb and As; Coriandrum sativum L. had higher capacity of redistributing $\mathrm{Sb}$ and As within the plant. Health risk assessment results showed that the hazard quotient (HQ) values of Sb and As in vegetables were in the ranges of 1.61-3.33 and 0.09-0.39, respectively; the chronic daily intake (CDI) and hazard quotient $(\mathrm{HQ})$ values of $\mathrm{Sb}$ were over the safe limit recommended by FAO and WHO, indicating that long-term consumption of vegetables from the surrounding soils of XKS mine may bring health risks to residents.

\section{Introduction}

Antimony ( $\mathrm{Sb}$ ), a nonessential toxic metal for life, widely exists in the lithosphere [1-3]. Microamount of Sb entering the human body will cause diseases to liver, skin, respiratory and cardiovascular systems, or even cancer [4-6]. Like arsenic (As), $\mathrm{Sb}$ and its compounds are listed as pollutants of priority interest by the United States Environment Protection Agency [7] and the European Union [8]. However, compared with the widespread studies on As, Sb has drawn relatively little attention $[9,10]$.

China is the world's largest antimony producer, and its average annual production of antimony accounts for $80 \%$ of the global produce [11]. Xikuangshan (XKS) in Hunan, the world's largest $\mathrm{Sb}$ mine, is reported to produce $25 \%$ of the world's $\mathrm{Sb}$. XKS mine has been under mining and smelting for over 110 years, and the longtime largescale mining and smelting operations caused severe As and $\mathrm{Sb}$ pollution to the local environment [12-14]. Generally, the concentrations of $\mathrm{Sb}$ and As are usually less than $10 \mathrm{mg} \mathrm{kg}^{-1}[3,15]$ in the nonpolluted soil, but they reach several thousand $\mathrm{mg} \mathrm{kg}^{-1}$ and several hundred $\mathrm{mg} \mathrm{kg}^{-1}$ in the mining areas (especially the areas near waste-rock piles, tailing piles, and smelters), respectively. Therefore, the plants grown around $\mathrm{Sb}$ mine accumulate high concentrations of $\mathrm{Sb}$ and As. For example, Agrostis capillaris L. grown around an Sb mine in Ribes Valley (Eastern Pyrenees) has a concentration of $\mathrm{Sb}$ and As of $68 \mathrm{mg} \mathrm{kg}^{-1}$ and $240 \mathrm{mg} \mathrm{kg}^{-1}$ in its buds [16]. Vegetables contain the vital elements for human health such as carbohydrates, protein, vitamins, fiber, and minerals, so they are people's essential dietary food [17]. However, the consumption of vegetables contaminated by heavy metals will impair human health severely [18]. In recent years, scholars had conducted studies on distribution, deposition of $\mathrm{Sb}$ and As in soils, bioavailability, health risk assessment, and concentration of $\mathrm{Sb}$ and As in plants around the Sb mines [19, 20], but few studies are concerned with the contamination 


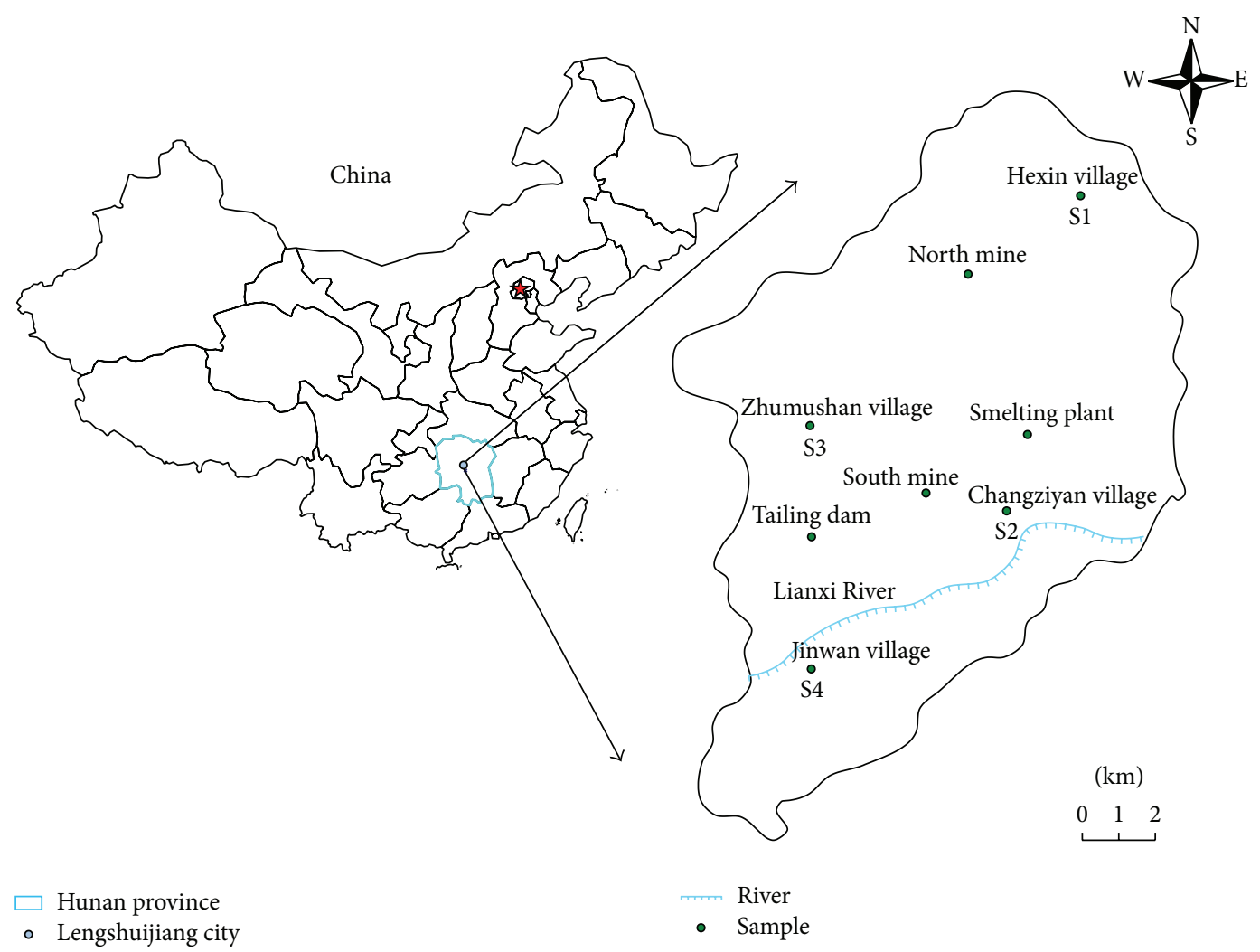

FIGURE 1: Map of sampling sites location.

of $\mathrm{Sb}$ and As in the soil-vegetable system and its health risk assessment.

Therefore, this study takes the soil-vegetable system around XKS Sb mine as the object and probes into the concentration of $\mathrm{Sb}$ and As in different parts of vegetables and assesses its health risks, aiming at providing guidance for the local residents to take safe vegetable consumption.

\section{Materials and Methods}

2.1. Study Area. XKS Sb mine, known as the "World's Antimony Capital," is located in Lengshuijiang city, Hunan prov-

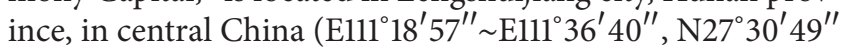
$\left.\sim 27^{\circ} 50^{\prime} 38^{\prime \prime}\right)$. It borders Lianyuan city in the east, Xinshao County in the south, and Xinhua County in the west and north, with a mining area of $70 \mathrm{~km}^{2}$ and an $\mathrm{Sb}$ reserve of 400,000 tons. XKS Sb mine has two parts: the South mine (Wuhua, Feishuiyan) and the North mine (Laokuangshan, Tongjiayuan). The ores are simple in composition, with stibnite as the ore mineral. The gangue minerals include quartz and calcite, with minor amounts of fluorite, barite, and secondary gypsum. The alteration of the host limestone is dominated by silicification and subordinately by carbonatization and, to a lesser extent, by baritization and fluoritization [21]. Lengshuijiang has the continental monsoon climate in subtropical zone, with the annual average temperature of $16-17.3^{\circ} \mathrm{C}$, annual average rainfall of $1354 \mathrm{~mm}$, and annual average relative humidity of $53.1 \%$. In January, the mean temperature is $4.9^{\circ} \mathrm{C}$, and in July the mean temperature is $28.2^{\circ} \mathrm{C}$.

2.2. Sample Collection. The soil and vegetable samples for test were collected from the vicinity of XKS Sb mine (Figure 1) in January 2015. Four sampling sites (S1-S4) were selected for this study: S1 is located in Hexin village, about $2.0 \mathrm{~km}$ away from the North mine; S2 is located in Changziyan village, less than $1.0 \mathrm{~km}$ away from the waste-rock piles in the South mine and the smelter; S3 is located in Zhumushan village, about $0.5 \mathrm{~km}$ away from the tailings dam; S4 is located in Jinwan village at the downstream of Lian River, about $3.5 \mathrm{~km}$ away from South mine. Specimens of the vegetable species were collected together with their corresponding soils. Totally, 60 soil samples and 60 vegetable samples of 10 species were collected, with 15 soils samples and 15 vegetables collected at each sampling site. The 10 vegetable species are as follows: Brassica pekinensis L. (BP), Brassica juncea L. (BJ), Allium fistulosum L. (AF), Allium sativum L. (AS), Raphanus sativus L. (RS), Daucus carota L. (DC), Coriandrum sativum L. (CS), Spinacia oleracea L. (SO), Chrysanthemum coronarium L. (CC), and Lactuca sativa L. (LS). Samples were collected in accordance with plum-point sampling method, which means that a vegetable sample together with their corresponding soil sample at the plough layer $(0-20 \mathrm{~cm}$ depth $)$ is collected at the center and its four equidistant points of the vegetable plot. The soils were collected with a stainless steel spatula and then put into the PTFE plastic sampling bags after being well mixed. 
The samples were sent to the laboratory for processing the same day.

2.3. Sample Treatment and Analytical Methods. Once in the laboratory, the vegetables were washed with tap water to remove the surface soil and rinsed with ultrasonic cleaning to further remove the residual soil and finally washed three times with ultrapure water $(18.0 \mathrm{M} \Omega \cdot \mathrm{cm})$ to remove pesticides and contaminants. All aboveground parts of vegetables were separated from the underground parts. When there was no water left on the vegetables, they were dried in an oven at $45^{\circ} \mathrm{C}$ until they reached constant weight. All the aboveground and underground parts were separately ground into powders with an agate mortar, sieved through a 100 mesh nylon sieve, and kept in Teflon bags until test. Soil samples were air dried in the laboratory, with biological debris, plant roots and leaves, and gravels excluded, ground and sieved through a 100 mesh nylon sieve, and then kept in Teflon bags.

The total amount of $\mathrm{Sb}$ and As in soil and vegetable parts was obtained with the method of USEPA-3050B. For the bioaccessibility tests of Sb and As, SBET (Simplified Bioaccessibility Extraction Test) is opted [19, 22]. First, 0.5 grams of edible vegetable parts (the edible parts of Raphanus sativus L. and Daucus carota L. are the underground, while the edible parts of other vegetables are aboveground) was placed in a centrifuge tube and mixed with $25 \mathrm{~mL}$ of amino acid solution $\left(0.4 \mathrm{~mol} \mathrm{~L}^{-1}, \mathrm{pH}=1.5\right.$ preadjusted with concentrated hydrochloric acid). This mixture was rotated end-over-end at $30 \mathrm{rpm}$ for 1 hour at $37^{\circ} \mathrm{C}$, centrifuged at high speed of $10000 \mathrm{r} \mathrm{min}^{-1}$ for 15 minutes in a high speed centrifuge (TGL16 M, Hunan Kaida, China), then filtered through a polyethylene syringe filter with a pore size of $0.2 \mu \mathrm{m}$, and diluted to $50 \mathrm{~mL}$. The content of Sb and As in all the samples was measured with Hydride Generation-Atomic Fluorescence Spectrometry (AFS-9700, Beijing Haiguang, China). All the parameters were listed in Table 1. Both Sb and As calibration curves showed good linearity $(r>0.999)$. The reagents used in sample processing and analysis were analytical reagents, from Sinopharm Chemical Reagent Co., Shanghai, China.

The relationship between the heavy metals contained in vegetables and those in soils can be calculated via bioaccumulation coefficient (BAC) and biotransfer coefficient (BTC) as follows:

$$
\begin{aligned}
\mathrm{BAC} & =\frac{C_{u}}{C_{s}}, \\
\mathrm{BTC} & =\frac{C_{a}}{C_{u}},
\end{aligned}
$$

wherein $C_{u}, C_{a}$, and $C_{s}$ represent the heavy metal concentration in underground and aboveground parts of vegetables and soil $\left(\mathrm{mg} \mathrm{kg}^{-1}\right)$, respectively.

2.4. Quality Control and Statistical Analysis. To assure the reliability of the test results, the standard reference samples of soil (GBW07406) and vegetable (GBW10015 (GSB-6)) obtained from the National Institute of Metrology were
TABLE 1: Instrumental and operative conditions of AFS-9700.

\begin{tabular}{lcc}
\hline Instrument parameters & $\mathrm{Sb}$ & $\mathrm{As}$ \\
\hline Photomultiplier voltage & $290 \mathrm{~V}$ & $300 \mathrm{~V}$ \\
Height of atomiser & $8 \mathrm{~mm}$ & $8 \mathrm{~mm}$ \\
Flow of carrier gas (Ar) & $300 \mathrm{~mL} \mathrm{~min}^{-1}$ & $300 \mathrm{~mL} \mathrm{~min}^{-1}$ \\
Lamp current & $70 \mathrm{~mA}$ & $50 \mathrm{~mA}$ \\
Flow of sheath gas (Ar) & $900 \mathrm{~mL} \mathrm{~min}^{-1}$ & $900 \mathrm{~mL} \mathrm{~min}^{-1}$ \\
Reading time & $12 \mathrm{~s}$ & $15 \mathrm{~s}$ \\
Delay time & $1 \mathrm{~s}$ & $1 \mathrm{~s}$ \\
Current carrying & $5 \% \mathrm{HCl}$ & $5 \% \mathrm{HCl}$ \\
Reaction liquid & $2 \% \mathrm{KBH}_{4}+$ & $2 \% \mathrm{KBH}_{4}+$ \\
& $0.5 \% \mathrm{NaOH}$ & $0.5 \% \mathrm{NaOH}$ \\
Measure method & Standard & Standard \\
Reading method & curve & curve \\
\hline
\end{tabular}

also digested in the same way with the collected samples of soils and vegetables. The test results of the reference standard samples were listed in Table 2. Meanwhile, in the test of collected soil and vegetable samples, reagent blank determinations were used, and $10 \%$ of all the samples were retested; the relative standard difference (RSD) between the two tests should be lower than $10 \%$.

The statistical package SPSS 17.0 was used for data analysis of $\mathrm{Sb}$ and As concentration in soils and vegetables. Statistical description was made on data of $\mathrm{Sb}$ and As concentration in 60 soil samples and 60 vegetable samples of 10 species with one-way ANOVA; correlation between Sb, As in soils and Sb, As in vegetables was determined using bivariate analysis. A significance level of $P<0.05$ was used throughout the study.

2.5. Health Risks to Residents from Heavy Metals in Vegetables. The previous studies usually examined the human consumption of water, food, and air to assess the health risks to residents around XKS Sb mine brought by the consumption of vegetables $[20,23]$. This research, however, based on the previous studies, employed the quotient of CDI (chronic daily intake) to assess the health risks to residents from $\mathrm{Sb}$ and $\mathrm{As}$ in vegetables. It can be calculated using the following formula:

$$
\mathrm{CDI}=\frac{C \times \mathrm{IR} \times \mathrm{ED} \times \mathrm{EF} \times F_{d}}{\mathrm{BW} \times \mathrm{AT} \times 365},
$$

wherein CDI stands for chronic daily intake $\left(\mathrm{mg} \mathrm{kg}^{-1} \mathrm{~d}^{-1}\right)$, $C$ is the concentration of heavy metals ( $\mathrm{Sb}$ and $\mathrm{As}$ ) in vegetables that may be absorbed by humans $\left(\mathrm{mg} \mathrm{kg}^{-1}\right)$, IR is the intake rate, per capita consumption of vegetables $\left(0.38 \mathrm{~kg} \mathrm{~d}^{-1}\right)$ [20], ED stands for exposure duration ( 25 years) [24], EF is exposed frequency ( $350 \mathrm{~d}$ year $\left.^{-1}\right)$ [24], $F_{d}$ is the ratio of vegetable fresh weight converted to dry weight (0.1) [25], BW is the average body weight $(61.8 \mathrm{~kg})$ [26], and AT is the average exposure time, assuming 72 years in this study [27]. RfD means reference dose, an index provided by the US Environmental Protection Agency [28] and the WHO [29] for the evaluation of toxic pollutants; the RfD values of $\mathrm{Sb}$ 
TABLE 2: Summary of measures of certified reference element concentration ( $\mathrm{mg} \mathrm{kg}^{-1}$, mean $\left.\pm \mathrm{SD}, n=3\right)$ in CRMs.

\begin{tabular}{ccccccc}
\hline & & GBW07406 & & & \multicolumn{2}{c}{ GBW10015 (GSB-6) } \\
& Certified value & Measured value & Recovery $^{\mathrm{a}}(\%)$ & Certified value & Measured value & Recovery (\%) \\
\hline $\mathrm{Sb}$ & $60 \pm 10$ & $58 \pm 1.5$ & 97 & $0.043 \pm 0.014$ & $0.040 \pm 0.004$ & 93 \\
$\mathrm{As}$ & $220 \pm 21$ & $210 \pm 6.5$ & 95 & $0.23 \pm 0.03$ & $0.22 \pm 0.01$ & 96 \\
\hline
\end{tabular}

Note: ${ }^{a}$ values quoted on dry weight basis; recovery $(\%)=($ mean measured value/mean certified value $) \times 100 \%$.

and As are $4 \times 10^{-4} \mathrm{mg} \mathrm{kg}^{-1} \mathrm{~d}^{-1}$ and $3 \times 10^{-4} \mathrm{mg} \mathrm{kg}^{-1} \mathrm{~d}^{-1}$. The health risks from consumption of metal contaminated vegetables were assessed based on the hazard quotient (HQ), which is calculated as follows:

$$
\mathrm{HQ}=\frac{\mathrm{CDI}}{\mathrm{RfD}}
$$

If the value of HQ is lower than 1 , it shows that the residents have no obvious health risks; if the value of HQ is equal to or higher than 1 , it indicates that the residents have relatively high health risks.

\section{Results and Discussion}

3.1. Analysis of Concentrations of Sb and As in XKS Mine Soils. Concentrations of $\mathrm{Sb}$ and As in the 60 soil samples from the four sampling sites were between $143.74 \sim 3947.68 \mathrm{mg} \mathrm{kg}^{-1}$ and $13.69 \sim 255.51 \mathrm{mg} \mathrm{kg}^{-1}$, respectively, and their mean values were $1267.20 \mathrm{mg} \mathrm{kg}^{-1}$ and $94.44 \mathrm{mg} \mathrm{kg}^{-1}$, respectively. These values were in accordance with those reported previously $[12,14,30]$.

The background concentrations of $\mathrm{Sb}$ and As in soils are $0.3 \sim 8.4 \mathrm{mg} \mathrm{kg}^{-1}$ [31] and $5 \sim 10 \mathrm{mg} \mathrm{kg}^{-1}$ [32] for the Earth, $1.06 \mathrm{mg} \mathrm{kg}^{-1}$ [33] and $9.2 \mathrm{mg} \mathrm{kg}^{-1}$ [34] for China, and $2.98 \mathrm{mg} \mathrm{kg}^{-1}$ and $14 \mathrm{mg} \mathrm{kg}^{-1}$ for Hunan [35], respectively. The concentrations of $\mathrm{Sb}$ and As in soils surrounding XKS mine were, respectively, 150 times, 1195 times, 425 times, 9.4 times, 10 times, and 6.7 times those of the Earth, China, and Hunan, much higher than the maximum value of $36 \mathrm{mg} \mathrm{kg}^{-1}$ and $8 \mathrm{mg} \mathrm{kg}^{-1}$ set by WHO. The results indicated that the soils around the XKS mine are seriously contaminated by $\mathrm{Sb}$ and As.

Meanwhile, the correlation analysis of the two variables showed that $\mathrm{Sb}$ and $\mathrm{As}$ in soils around the mine have significant positive correlation $(r=0.755, P<0.05, n=60)$, indicating that the two elements have a high homology. This may be caused by the fact that the soil contaminations of $\mathrm{Sb}$ and As are from mining, smelting, and tailings dust and that $\mathrm{Sb}$ and As are closely associated congeners, having similar chemical properties as well as similar geochemical behavior [36].

The ANOVA analysis of the concentrations of $\mathrm{Sb}$ and As in soils from the four sampling sites showed significant differences $\left(F_{\mathrm{Sb}}=128.56, P_{\mathrm{Sb}}=0.00 ; F_{\mathrm{As}}=90.83, P_{\mathrm{As}}=0.00\right)$. The mean values of $\mathrm{Sb}$ and As soil concentrations in the four sampling sites (S1, S2, S3, and S4) were shown in Figure 2. The average $\mathrm{Sb}$ concentrations of the four sampling sites were $405.04 \mathrm{mg} \mathrm{kg}^{-1}, 2641.55 \mathrm{mg} \mathrm{kg}^{-1}, 1596.57 \mathrm{mg} \mathrm{kg}^{-1}$, and

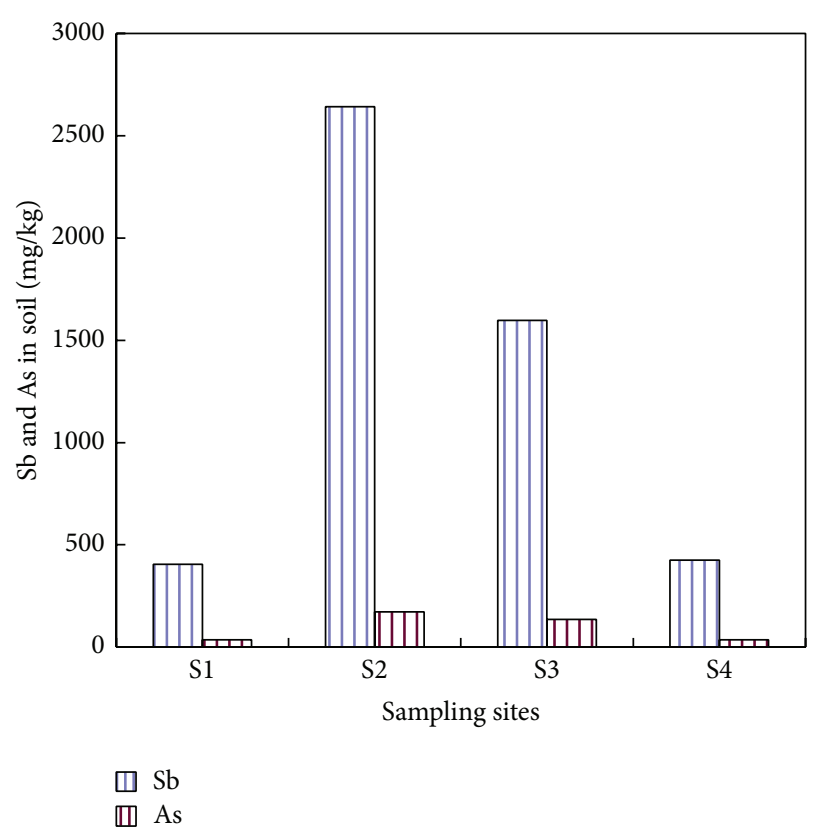

FIgURE 2: $\mathrm{Sb}$ and As distribution in soil of four sampling sites.

$425.67 \mathrm{mg} \mathrm{kg}^{-1}$, respectively, while the average As concentrations were $34.86 \mathrm{mg} \mathrm{kg}^{-1}, 172.44 \mathrm{mg} \mathrm{kg}^{-1}, 135.19 \mathrm{mg} \mathrm{kg}^{-1}$, and $35.27 \mathrm{mg} \mathrm{kg}^{-1}$. The extent of contaminations of $\mathrm{Sb}$ and As in soils formed such an order as S2 $>$ S3 $>$ S4 $>$ S1. Sampling site S2, located near the South mine waste-rock piles and smelting slag piles, is most serious in Sb and As pollution, which may be coinfluenced by smelting dust, rain leaching of mining waste-rock and smelting slag, and mining waste water. Sampling site S3, located near the tailings dam, also has a higher concentration of Sb and As in soils, partly because of the dry and wet deposition of tailings dust as well as the mining waste water. Sampling sites S1 and S4 have relatively lighter contaminations of $\mathrm{Sb}$ and $\mathrm{As}$ in soils; the reasons may be that $S 1$ is $2.0 \mathrm{~km}$ away from the North mine, with its location being higher than the North mine, and S4 is much far away from the mine, but local residents irrigated vegetables with the water from Lianxi River that was contaminated by mining and smelting, so its concentration of $\mathrm{Sb}$ and As in soil is similar to that of S1.

This suggests that mining and smelting activities in XKS mine have caused serious pollution to the surrounding soils. The less the distance away from the mine, the more severe the contamination. 


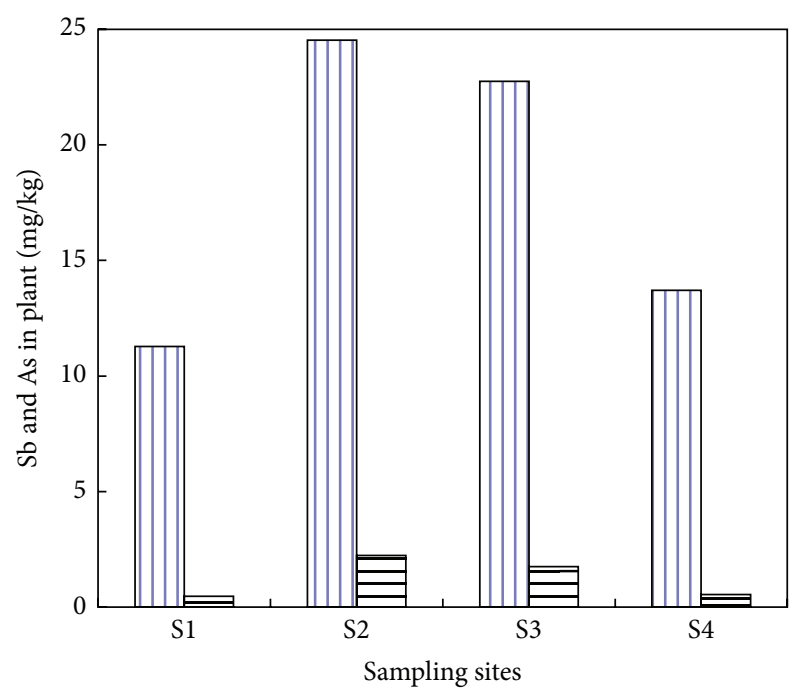

ए $\mathrm{Sb}$

曰 As

Figure 3: Mean concentration of Sb and As in vegetables collected in different sites.

3.2. Distribution of $\mathrm{Sb}$ and As in Vegetables from Various Sampling Sites. Residents surrounding XKS mine consume the vegetables they grow there. A total of 60 vegetable samples of 10 species were collected from the four sampling sites. The vegetable samples from the same sampling site formed an entity. The concentrations of $\mathrm{Sb}$ and $\mathrm{As}$ in vegetables from the four sites were shown in Figure 3. The ANOVA analysis indicated that the underground parts of vegetables from the four sampling sites showed a significant difference $\left(F_{\mathrm{Sb}}=6.52\right.$, $\left.P_{\mathrm{Sb}}=0.001 ; F_{\mathrm{As}}=30.84, P_{\mathrm{As}}=0.000\right)$. Vegetables in S2 had the highest average concentrations of $\mathrm{Sb}\left(24.53 \mathrm{mg} \mathrm{kg}^{-1}\right)$ and $\mathrm{As}$ $\left(2.23 \mathrm{mg} \mathrm{kg}^{-1}\right)$, and vegetables in S1 had the lowest average concentration of $\mathrm{Sb}\left(11.27 \mathrm{mg} \mathrm{kg}^{-1}\right)$ and As $\left(0.47 \mathrm{mg} \mathrm{kg}^{-1}\right)$, which corresponded, respectively, to the Sb and As concentrations in soils of S2 and S1. Correlation studies showed that $\mathrm{Sb}$ and $\mathrm{As}$ in the underground parts of vegetables and in soils from the four sampling sites had significant correlation $\left(r_{\mathrm{Sb}}=\right.$ $\left.0.52, P_{\mathrm{Sb}}<0.05 ; r_{\mathrm{As}}=0.81, P_{\mathrm{As}}<0.05\right)$.

\subsection{Concentration Distribution and Accumulation of $\mathrm{Sb}$ and} As in Different Vegetables. The plants grown in the uncontaminated soils have a background concentration of $\mathrm{Sb}$ and As ranging between $2-50 \mu \mathrm{g} \mathrm{kg}^{-1}[37,38]$ and $0.01 \sim$ $1.5 \mathrm{mg} \mathrm{kg}^{-1}$ [39], respectively. The concentrations of $\mathrm{Sb}$ and As in different plants vary, depending on the nature of the soils and the migration of $\mathrm{Sb}$ and $\mathrm{As}$ in contaminated soils $[6,40]$. Studies have shown that plants with Sb concentration of $5-10 \mathrm{mg} \mathrm{kg}^{-1}$ are of toxicity [41], but $\mathrm{He}$ [30] pointed out that plants with the $\mathrm{Sb}$ concentration of $5 \mathrm{mg} \mathrm{kg}^{-1}$ would be toxic and that it would stimulate the growth of plants if the As concentration is less than $10 \mathrm{mg} \mathrm{kg}^{-1}$, while it would toxicate the plants if over $50 \mathrm{mg} \mathrm{kg}^{-1}$ [42]. The 60 vegetable samples of 10 species collected from XKS mine had average

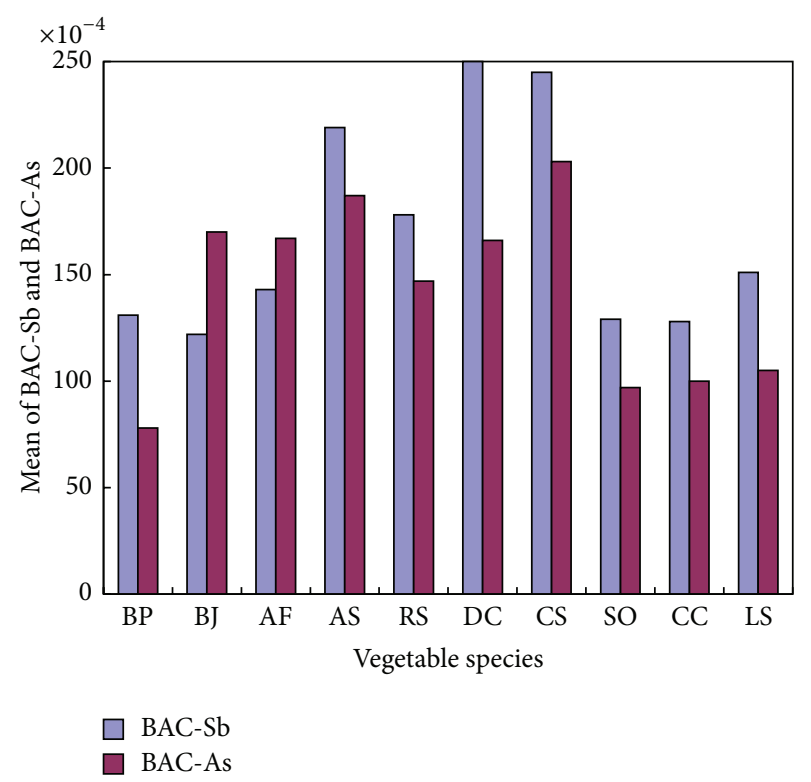

Figure 4: Mean BAC of Sb and As in 10 species.

concentrations of $\mathrm{Sb}$ and As of $6.65 \mathrm{mg} \mathrm{kg}^{-1} \sim 29.31 \mathrm{mg} \mathrm{kg}^{-1}$ and $0.61 \mathrm{mg} \mathrm{kg}^{-1} \sim 1.73 \mathrm{mg} \mathrm{kg}^{-1}$ respectively, indicating that $\mathrm{Sb}$ in soils exerts a certain inhibition on vegetable growth, but As has little effect on vegetable growth.

The heavy metal concentrations in different parts of vegetables showed great differences [30]. The concentrations of $\mathrm{Sb}$ and $\mathrm{As}$ in the collected 10 species of vegetables were in Table 3. As shown in Table 3, the underground part of Daucus carota $\mathrm{L}$. had the highest $\mathrm{Sb}$ concentration (mean value: $23.72 \mathrm{mg} \mathrm{kg}^{-1}$ ), and the underground part of Allium fistulosum L. had the highest As concentration (mean value: $2.08 \mathrm{mg} \mathrm{kg}^{-1}$ ). The underground part of Brassica pekinensis L. had the lowest $\mathrm{Sb}$ and As concentrations (mean value: $7.76 \mathrm{mg} \mathrm{kg}^{-1}$ and $0.60 \mathrm{mg} \mathrm{kg}^{-1}$, resp.) and the aboveground part of Raphanus sativus L. had the highest Sb concentration (mean value: $37.39 \mathrm{mg} \mathrm{kg}^{-1}$ ). The aboveground part of Coriandrum sativum L. had the highest As concentration (mean value: $2.06 \mathrm{mg} \mathrm{kg}^{-1}$ ) and the aboveground part of Brassica pekinensis L. had the lowest $\mathrm{Sb}$ and As concentrations (mean value: $5.85 \mathrm{mg} \mathrm{kg}^{-1}$ and $0.63 \mathrm{mg} \mathrm{kg}^{-1}$, resp.).

Vegetables had different cumulative capacity of $\mathrm{Sb}$ and As. The differences of $\mathrm{Sb}$ and As concentration in soils can be eliminated via BAC calculation, and the mean bioaccumulation coefficients (BAC) of the 10 species of vegetables were obtained in Figure 4. As can be seen from the figure, the average $\mathrm{BAC}_{\mathrm{Sb}}$ and $\mathrm{BAC}_{\mathrm{As}}$ values of all vegetables were less than 0.03 , indicating that the bioavailability of $\mathrm{Sb}$ and As in soils from the four sampling sites is very low. As for the vegetables, Daucus carota $\mathrm{L}$. had a higher value of $\mathrm{BAC}_{\mathrm{Sb}}$ (0.0250), indicating that Daucus carota L. has advantages over others in absorbing Sb from soils, and Coriandrum sativum L. had a higher value of $\mathrm{BAC}_{\mathrm{As}}(0.0203)$, indicating that it has a strong ability in absorbing As from soils. 


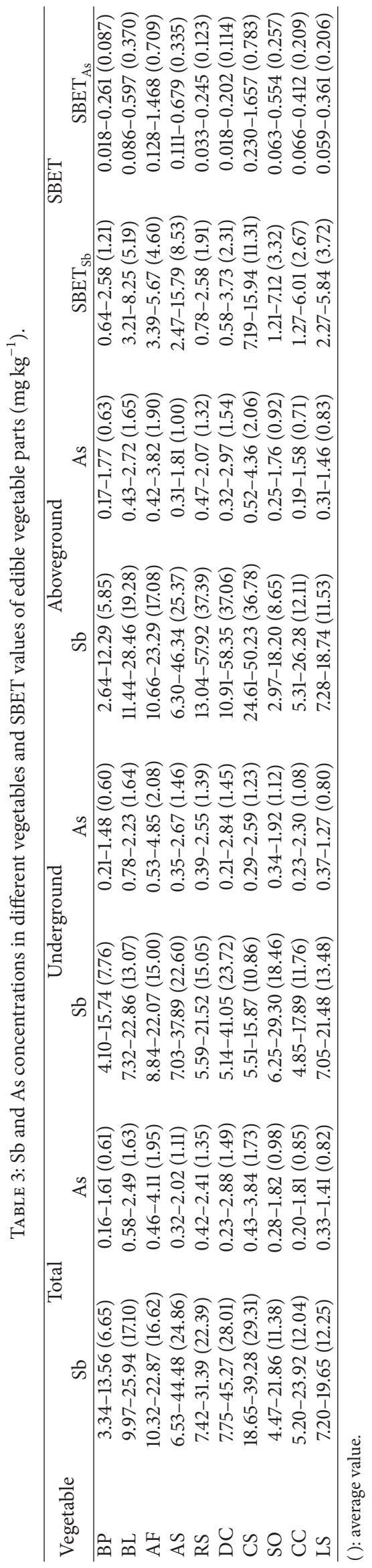




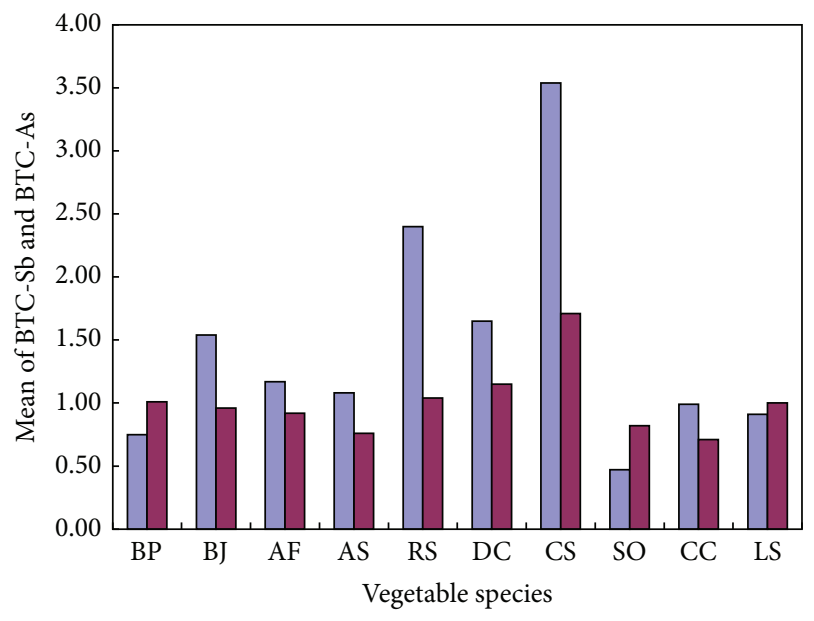

$\square$ BTC-Sb
BTC-As

FIgUre 5: Mean BTC of Sb and As in 10 species.

Concentrations of $\mathrm{Sb}$ and As were not uniform in different parts of certain plants. For example, the 19 kinds of vegetables and crops such as carrots, onions, and tomatoes had the $\mathrm{Sb}$ concentrations of $0.02-0.09 \mathrm{mg} \mathrm{kg}^{-1}$ in the underground part, but they had $\mathrm{Sb}$ concentrations of $0.02-2.2 \mathrm{mg} \mathrm{kg}^{-1}$ in stems and leaves [23]. Mentha aquatica had an As concentration of $540 \mathrm{mg} \mathrm{kg}^{-1}$ in root but had As concentration of $216 \mathrm{mg} \mathrm{kg}^{-1}$ in leaves [43]. BTC can be used to evaluate the distribution of $\mathrm{Sb}$ and As in the underground and aboveground parts of the plants. The higher the values of the BTC are, the more efficiently the heavy metals are transferred to the aboveground parts through the roots [44]. The mean values of $\mathrm{BTC}_{\mathrm{Sb}}$ and $\mathrm{BTC}_{\mathrm{As}}$ of vegetable samples were shown in Figure 5. As indicated in Figure 5, among the 10 species of vegetables, the mean values of $\mathrm{BTC}_{\mathrm{Sb}}$ and $\mathrm{BTC}_{\mathrm{As}}$ of Raphanus sativus L., Daucus carota L., and Coriandrum sativum L. were higher than 1.0. In particular, the mean values of $\mathrm{BTC}_{\mathrm{Sb}}$ and $\mathrm{BTC}_{\mathrm{As}}$ of Coriandrum sativum $\mathrm{L}$. were even up to 3.54 and 1.71, respectively. The results indicated that the mentioned three vegetables have a strong ability in transferring $\mathrm{Sb}$ and As aboveground through the roots; that is to say, the three species of vegetables have a strong redistributive capacity of $\mathrm{Sb}$ and As.

3.4. Assessment of Health Risks Caused by Sb and As. The previous researches calculated the HQ and CDI values of heavy metals from food intake on the assumption that the heavy metals contained in vegetables were $100 \%$ absorbed by human beings $[20,45]$, which obviously unscientifically enlarged the health risk.

In fact, instead of being completely absorbed by the body, a large proportion of heavy metals were excreted out $[46,47]$, so the method of SBET is practical to calculate the availability of $\mathrm{Sb}$ and $\mathrm{As}$ in the edible vegetable parts. The SBET values of $\mathrm{Sb}$ and $\mathrm{As}$ in the edible parts of 10 species of vegetables were in Table 3 . The calculation results of chronic daily intake (CDI)
TABLE 4: Daily dietary intake of $\mathrm{Sb}$ and As from vegetables and health risk index.

\begin{tabular}{lccc}
\hline Sampling sites & Heavy metals & CDI $\left(\mathrm{mg} \mathrm{kg}^{-1} \mathrm{~d}^{-1}\right)$ & HQ \\
\hline \multirow{2}{*}{ S1 } & $\mathrm{Sb}$ & $6.43 \times 10^{-4}$ & 1.61 \\
& $\mathrm{As}$ & $0.26 \times 10^{-4}$ & 0.09 \\
\hline \multirow{2}{*}{ S2 } & $\mathrm{Sb}$ & $13.31 \times 10^{-4}$ & 3.33 \\
& $\mathrm{As}$ & $1.18 \times 10^{-4}$ & 0.39 \\
\hline \multirow{2}{*}{ S3 } & $\mathrm{Sb}$ & $9.81 \times 10^{-4}$ & 2.45 \\
& $\mathrm{As}$ & $0.88 \times 10^{-4}$ & 0.29 \\
\hline \multirow{2}{*}{ S4 } & $\mathrm{Sb}$ & $7.10 \times 10^{-4}$ & 1.78 \\
& $\mathrm{As}$ & $0.31 \times 10^{-4}$ & 0.10 \\
\hline
\end{tabular}

and hazard quotient (HQ) of $\mathrm{Sb}$ and As that residents in the four sampling sites around XKS mine absorbed were shown in Table 4.

As can be seen from Table $4, \mathrm{CDI}_{\mathrm{Sb}}$ of the residents in the sampling areas is higher than the limit $\left(\mathrm{RfD}_{\mathrm{Sb}}=4 \times\right.$ $10^{-4} \mathrm{mg} \mathrm{kg}^{-1} \mathrm{~d}^{-1}$ ) recommended by USEPA and WHO, with $\mathrm{CDI}_{\mathrm{Sb}}$ in S2 being the highest $\left(13.31 \times 10^{-4} \mathrm{mg} \mathrm{kg}^{-1} \mathrm{~d}^{-1}\right)$; $\mathrm{CDI}_{\mathrm{As}}$ is lower than the recommended limit $\left(\mathrm{RfD}_{\mathrm{As}}=3 \times\right.$ $10^{-4} \mathrm{mg} \mathrm{kg}^{-1} \mathrm{~d}^{-1}$ ). The average chronic daily intake of $\mathrm{Sb}$ is significantly greater than that of As.

Hazard quotient (HQ) is a useful parameter to assess health risks brought by the consumption of food contaminated with heavy metals [48]. The $\mathrm{HQ}_{\mathrm{Sb}}$ index values of the four sampling areas were all higher than $1.0(1.61,3.33,2.45$, and 1.78 , resp.), indicating that the vegetables have obvious health risks on human health; $\mathrm{HQ}_{\mathrm{As}}$ was lower than 0.4, indicating that As in vegetables brings less health risks to people than $\mathrm{Sb}$.

According to the research, the heavy metal $\mathrm{Sb}$ in vegetables brings higher HQ to the local residents than As. Therefore, it is highly important to take appropriate measures to control the heavy metal contamination in soils around XKS mine and to bring the accumulation of heavy metals in the edible parts of vegetables to a safe level.

\section{Conclusions}

From the results of the soil and vegetable samples collected, we came to a better knowledge that mining and smelting of $\mathrm{Sb}$ greatly impacted the surrounding environment and brought potential risks to people's health. The contamination of Sb and As in soils of the four sampling sites formed such an order, S2 $>$ S3 $>$ S1 $>$ S4, which indicates that the contamination of $\mathrm{Sb}$ and As in soils diminishes with distance from the mine and slag piles. The concentration of $\mathrm{Sb}$ and $\mathrm{As}$ in vegetable samples from the four sampling sites varied. Among the 10 species of vegetables, Coriandrum sativum L. has the highest concentration of Sb, and Allium fistulosum L. has the highest concentration of As, while Brassica pekinensis L. has the lowest concentration of both $\mathrm{Sb}$ and As. The accumulations of $\mathrm{Sb}$ and $\mathrm{As}$ in various vegetables were narrowly different (both $\mathrm{BAC}_{\mathrm{Sb}}$ and $\mathrm{BAC}_{\mathrm{As}}$ were less than 0.03), but the distribution of $\mathrm{Sb}$ and $\mathrm{As}$ in various vegetables was severely different (especially Coriandrum sativum L., $\mathrm{BTC}_{\mathrm{Sb}}=3.54$, 
$\left.\mathrm{BTC}_{\mathrm{As}}=1.71\right)$. The calculation of CDI and HQ showed that the health risks to local residents caused by $\mathrm{Sb}$ in vegetables are much higher than As. Therefore, effective measures must be taken to control the toxic heavy metal pollution, especially the pollution caused by $\mathrm{Sb}$ in the surrounding areas of XKS mine.

\section{Conflict of Interests}

The authors declare that there is no conflict of interests regarding the publication of this paper.

\section{Acknowledgments}

This research work was financially supported by the National Natural Science Foundation of China (no. 51174090 and no. 42472328) and MOE (Ministry of Education in China) Project of Humanities and Social Science (no. 13YJCZH276 and no. 14YJA630039).

\section{References}

[1] M. Filella, P. A. Williams, and N. Belzile, "Antimony in the environment: knowns and unknowns," Environmental Chemistry, vol. 6, no. 2, pp. 95-105, 2009.

[2] D. Amarasiriwardena and F. C. Wu, "Antimony: emerging toxic contaminant in the environment," Microchemical Journal, vol. 97, no. 1, pp. 1-3, 2011.

[3] S. C. Wilson, P. V. Lockwood, P. M. Ashley, and M. Tighe, “The chemistry and behaviour of antimony in the soil environment with comparisons to arsenic: a critical review," Environmental Pollution, vol. 158, no. 5, pp. 1169-1181, 2010.

[4] K. Kuroda, G. Endo, A. Okamoto, Y. S. Yoo, and S.-I. Horiguchi, "Genotoxicity of beryllium, gallium and antimony in shortterm assays," Mutation Research Letters, vol. 264, no. 4, pp. 163$170,1991$.

[5] T. M. Schnorr, K. Steenland, M. J. Thun, and R. A. Rinsky, "Mortality in a cohort of antimony smelter workers," The American Journal of Industrial Medicine, vol. 27, no. 5, pp. 759-770, 1995.

[6] E. Álvarez-Ayuso, V. Otones, A. Murciego, A. García-Sánchez, and I. S. Regina, "Antimony, arsenic and lead distribution in soils and plants of an agricultural area impacted by former mining activities," Science of the Total Environment, vol. 439, pp. 35-43, 2012.

[7] USEPA, Water Related Fate of the 129 Priority Pollutants, USEPA, Washington, DC, USA, 1979.

[8] M. Filella, N. Belzile, and Y.-W. Chen, "Antimony in the environment: a review focused on natural waters. I. Occurence," EarthScience Reviews, vol. 57, no. 1-2, pp. 125-176, 2002.

[9] K. Telford, W. Maher, F. Krikowa et al., "Bioaccumulation of antimony and arsenic in a highly contaminated stream adjacent to the Hillgrove Mine, NSW, Australia," Environmental Chemistry, vol. 6, no. 2, pp. 133-143, 2009.

[10] M. Tighe, P. M. Ashley, P. V. Lockwood, and S. Wilson, "Soil, water, and pasture enrichment of antimony and arsenic within a coastal floodplain system," Science of the Total Environment, vol. 347, no. 1-3, pp. 175-186, 2005.

[11] US Geological Survey, Mineral Commodity Summaries 2013, US Geological Survey, Washington, DC, USA, 2013.

[12] Z. Y. Fu, F. C. Wu, D. Amarasiriwardena et al., "Antimony, arsenic and mercury in the aquatic environment and fish in a large antimony mining area in Hunan, China," Science of the Total Environment, vol. 408, no. 16, pp. 3403-3410, 2010.

[13] X. Q. Wang, M. C. He, J. H. Xi, and X. F. Lu, "Antimony distribution and mobility in rivers around the world's largest antimony mine of Xikuangshan, Hunan Province, China," Microchemical Journal, vol. 97, no. 1, pp. 4-11, 2011.

[14] C. Y. Wei, Z. F. Ge, W. S. Chu, and R. W. Feng, "Speciation of antimony and arsenic in the soils and plants in an old antimony mine," Environmental and Experimental Botany, vol. 109, pp. 3139, 2015.

[15] W. J. Fitz and W. W. Wenzel, "Arsenic transformations in the soil-rhizosphere-plant system: fundamentals and potential application to phytoremediation," Journal of Biotechnology, vol. 99, no. 3, pp. 259-278, 2002.

[16] J. Bech, I. Corrales, P. Tume et al., "Accumulation of antimony and other potentially toxic elements in plants around a former antimony mine located in the Ribes Valley (Eastern Pyrenees)," Journal of Geochemical Exploration, vol. 113, pp. 100-105, 2012.

[17] Suruchi and P. Khanna, "Assessment of heavy metal contamination in different vegetables grown in and around urban areas," Research Journal of Environmental Toxicology, vol. 5, no. 3, pp. 162-179, 2011.

[18] C. A. Dyer, "Heavy metals as endocrine disrupting chemicals," in Endocrine-Disrupting Chemicals: From Basic Research to Clinical Practice, A. C. Gore, Ed., Humana Press, Totowa, NJ, USA, 2007.

[19] J. L. Li, Y. Wei, L. Zhao et al., "Bioaccessibility of antimony and arsenic in highly polluted soils of the mine area and health risk assessment associated with oral ingestion exposure," Ecotoxicology and Environmental Safety, vol. 110, pp. 308-315, 2014.

[20] F. C. Wu, Z. Y. Fu, B. J. Liu et al., "Health risk associated with dietary co-exposure to high levels of antimony and arsenic in the world's largest antimony mine area," Science of the Total Environment, vol. 409, no. 18, pp. 3344-3351, 2011.

[21] J. T. Peng and R. Z. Hu, "Carbon and oxygen isotope systematics in the Xikangshan giant antimony deposit, central Hunan," Geological Review, vol. 47, no. 1, pp. 34-41, 1991.

[22] V. Ettler, B. Kř́bek, V. Majer, I. Knésl, and M. Mihaljevič, “Differences in the bioaccessibility of metals/metalloids in soils from mining and smelting areas (Copperbelt, Zambia)," Journal of Geochemical Exploration, vol. 113, pp. 68-75, 2012.

[23] W. Hammel, R. Debus, and L. Steubing, "Mobility of antimony in soil and its availability to plants," Chemosphere, vol. 41, no. 11, pp. 1791-1798, 2000.

[24] USEPA, Supplemental Guidance for Developing Soil Screening Levels for Superfund Sites, 2002, http://www.epa.gov/superfund/health/conmedia/soil/pdfs/ssg_main.pdf.

[25] L. Zhang and X. C. Zhang, "Interactions of nitrogen with water and light in the growth of plant," Agricultural Research in the Arid Areas, vol. 21, no. 1, pp. 43-46, 2003.

[26] MHC, Health Statistical Yearbook of China 2008, Ministry of Health of China, 2008.

[27] WHO, World Health Report, World Health Organization, Geneva, Switzerland, 2006.

[28] USEPA, Risk-Based Concentration Table, United States Environmental Protection Agency, Philadelphia, Pa, USA, 2000.

[29] WHO, "Evaluation of certain food additives and contaminants (41st report of the joint FAO/WHO expert committee on food additives)," WHO Technical Report Series 837, World Health Organization, Geneva, Switzerland, 1993. 
[30] M. C. He, "Distribution and phytoavailability of antimony at an antimony mining and smelting area, Hunan, China," Environmental Geochemistry \& Health, vol. 29, no. 3, pp. 209-219, 2007.

[31] C. A. Johnson, H. Moench, P. Wersin, P. Kugler, and C. Wenger, "Solubility of antimony and other elements in samples taken from shooting ranges," Journal of Environmental Quality, vol. 34, no. 1, pp. 248-254, 2005.

[32] W. Q. Qi and J. S. Cao, "Study on the soil background value of antimony," Chinese Journal of Soil Science, vol. 22, no. 5, pp. 209210, 1991.

[33] R. W. Boyle and I. R. Jonasson, "The geochemistry of arsenic and its use as an indicator element in geochemical prospecting," Journal of Geochemical Exploration, vol. 2, no. 3, pp. 251-296, 1973.

[34] G. X. Zhang, J. R. Yang, and L. Hua, "Ecological effect of arsenic in soil," Soils, no. 2, pp. 64-68, 1996.

[35] Y. Pan and G. Yang, Background Value of Soils in Hunan and Their Investigation Methods, China Environmental Science Press, Beijing, China, 1988.

[36] M. O. Andreae and P. N. Froelich Jr., "Arsenic, antimony, and germanium biogeochemistry in the Baltic Sea," Tellus Series BChemical and Physical Meteorology, vol. 36, no. 2, pp. 101-117, 1984.

[37] A. M. Murciego, A. G. Sánchez, M. A. R. González et al., "Antimony distribution and mobility in topsoils and plants (Cytisus striatus, Cistus ladanifer and Dittrichia viscosa) from polluted Sb-mining areas in Extremadura (Spain)," Environmental Pollution, vol. 145, no. 1, pp. 15-21, 2007.

[38] M. Tschan, B. H. Robinson, M. Nodari, and R. Schulin, "Antimony uptake by different plant species from nutrient solution, agar and soil," Environmental Chemistry, vol. 6, no. 2, pp. 144$152,2009$.

[39] A. Kabata-Pendias and M. Mukherjee, "Trace elements of group 15 (previously group Va)," in Trace Elements from Soil to Human, Springer, New York, NY, USA, 2007.

[40] M. Tighe, P. V. Lockwood, P. M. Ashley, R. D. Murison, and S. C. Wilson, "The availability and mobility of arsenic and antimony in an acid sulfate soil pasture system," Science of the Total Environment, vol. 463-464, no. 5, pp. 151-160, 2013.

[41] A. Kabata-Pendias and H. Pendias, Trace Elements in Soils and Plants, CRC Press, Boca Raton, Fla, USA, 3rd edition, 2001.

[42] R. Mascher, B. Lippmann, S. Holzinger, and H. Bergmann, "Arsenate toxicity: effects on oxidative stress response molecules and enzymes in red clover plants," Plant Science, vol. 163, no. 5, pp. 961-969, 2002.

[43] F. Baroni, A. Boscagli, L. A. Di Lella, G. Protano, and F. Riccobono, "Arsenic in soil and vegetation of contaminated areas in southern Tuscany (Italy)," Journal of Geochemical Exploration, vol. 81, no. 1-3, pp. 1-14, 2004.

[44] R. R. Brook, Biologicheskie Metody Poiskov Poleznykh Iskopae$m y k h$, Nedra, Moscow, Russia, 1986.

[45] M. Izquierdo, E. De Miguel, M. Ortega, and J. Mingot, "Bioaccessibility of metals and human health risk assessment in community urban gardens," Chemosphere, vol. 135, pp. 312-318, 2015.

[46] B. A. Fowler and P. L. Goering, "Antimony," in Metals and Their Compounds in the Environment, VCH, New York, NY, USA, 1991.

[47] H. Horiguchi, E. Oguma, S. Sasaki et al., "Dietary exposure to cadmium at close to the current provisional tolerable weekly intake does not affect renal function among female Japanese farmers," Environmental Research, vol. 95, no. 1, pp. 20-31, 2004.
[48] N. Sridhara Chary, C. T. Kamala, and D. Samuel Suman Raj, "Assessing risk of heavy metals from consuming food grown on sewage irrigated soils and food chain transfer," Ecotoxicology and Environmental Safety, vol. 69, no. 3, pp. 513-524, 2008. 

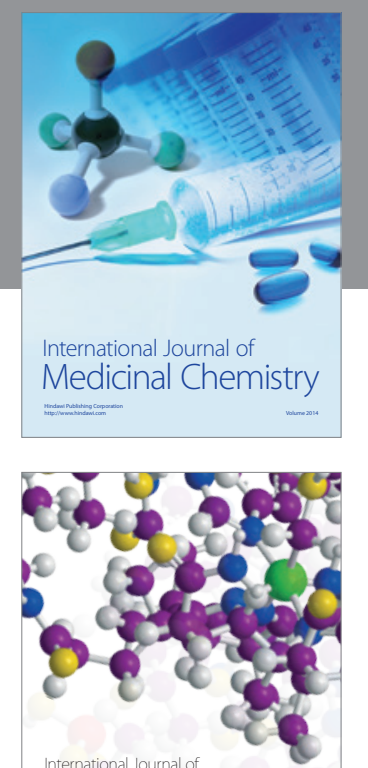

\section{Carbohydrate} Chemistry

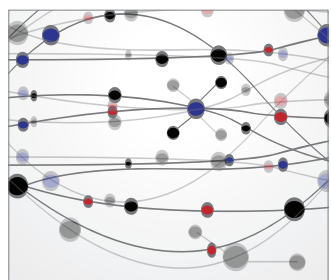

The Scientific World Journal
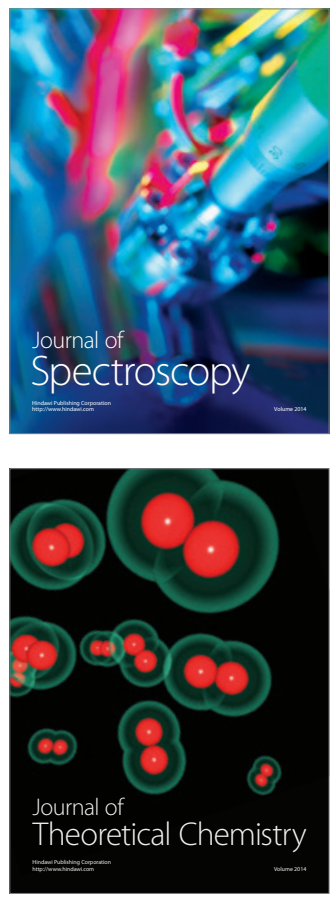
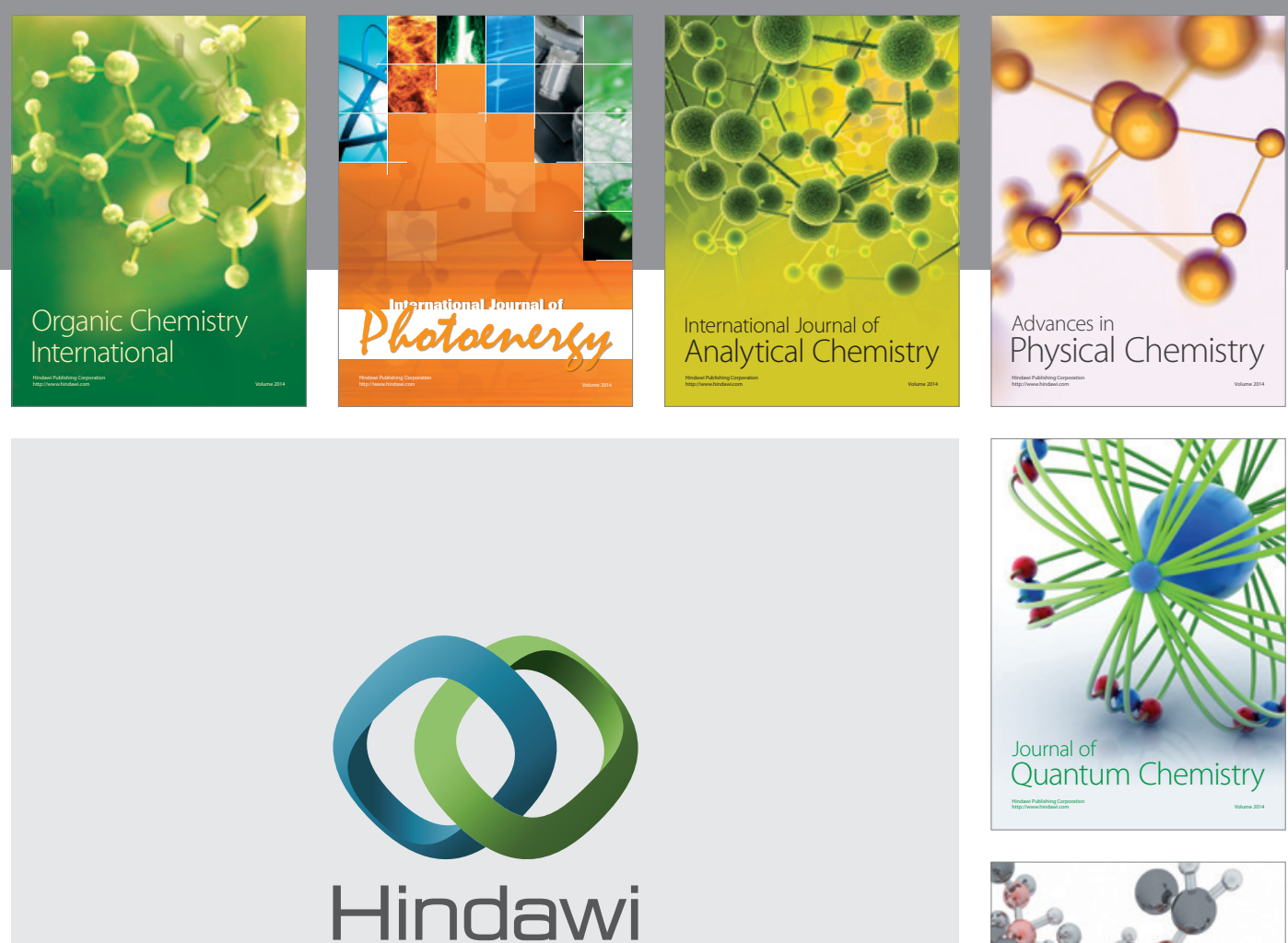

Submit your manuscripts at

http://www.hindawi.com

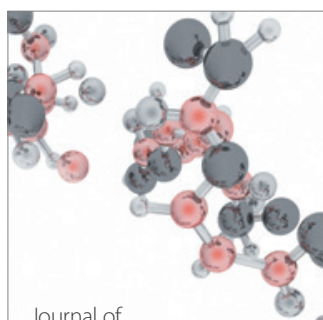

Analytical Methods

in Chemistry

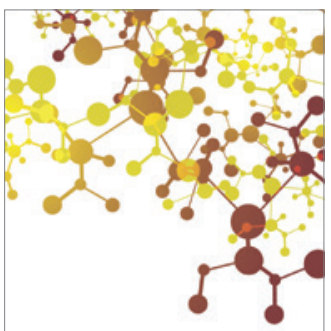

Journal of

Applied Chemistry

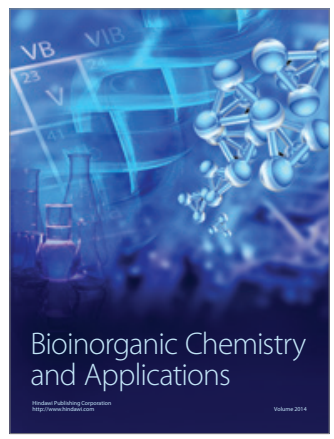

Inorganic Chemistry
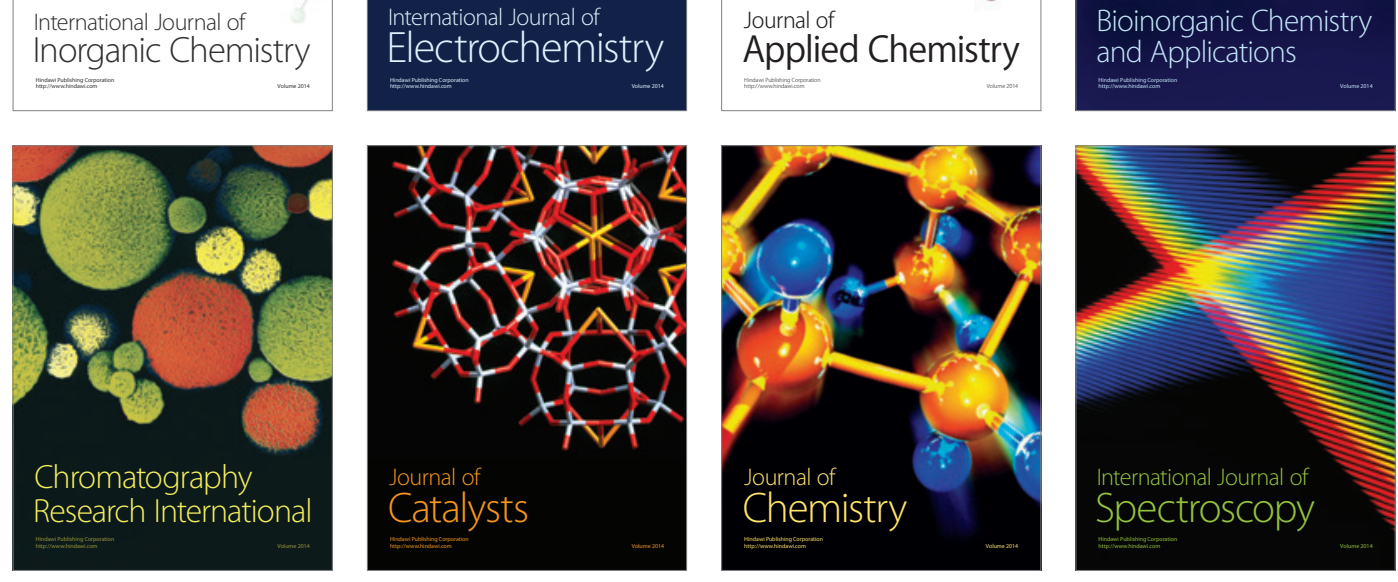